IZA DP No. 8098

Are Voluntary Agreements Better?

Evidence from Baseball Arbitration

John W. Budd

Aaron J. Sojourner

Jaewoo Jung

April 2014 


\title{
Are Voluntary Agreements Better? Evidence from Baseball Arbitration
}

\author{
John W. Budd \\ University of Minnesota \\ Aaron J. Sojourner \\ University of Minnesota \\ and IZA \\ Jaewoo Jung \\ Korea Labor Institute
}

Discussion Paper No. 8098

April 2014

IZA
P.O. Box 7240
53072 Bonn
Germany

Phone: +49-228-3894-0

Fax: +49-228-3894-180

E-mail: iza@iza.org

Any opinions expressed here are those of the author(s) and not those of IZA. Research published in this series may include views on policy, but the institute itself takes no institutional policy positions. The IZA research network is committed to the IZA Guiding Principles of Research Integrity.

The Institute for the Study of Labor (IZA) in Bonn is a local and virtual international research center and a place of communication between science, politics and business. IZA is an independent nonprofit organization supported by Deutsche Post Foundation. The center is associated with the University of Bonn and offers a stimulating research environment through its international network, workshops and conferences, data service, project support, research visits and doctoral program. IZA engages in (i) original and internationally competitive research in all fields of labor economics, (ii) development of policy concepts, and (iii) dissemination of research results and concepts to the interested public.

IZA Discussion Papers often represent preliminary work and are circulated to encourage discussion. Citation of such a paper should account for its provisional character. A revised version may be available directly from the author. 
IZA Discussion Paper No. 8098

April 2014

\section{ABSTRACT}

\section{Are Voluntary Agreements Better? Evidence from Baseball Arbitration*}

This paper empirically examines the widespread belief that voluntarily negotiated agreements produce better long-run relationships than third-party imposed settlements, such as arbitrator decisions or court judgments. Two key outcomes are analyzed - subsequent player performance and the durability of club-player relationship. Major League Baseball provides a compelling setting for these analyses because individual performance is well measured, there is the possibility of relationship breakdown, and both voluntary and imposed settlements are routinely used. While the results clearly show that a third-party imposed settlement is not better than a voluntary one, the evidence in support of the widespread belief is mixed.

JEL Classification: dispute resolution, arbitration, negotiation, salary, sports, baseball

Keywords: J52, M12, M5

Corresponding author:

John W. Budd

Center for Human Resources and Labor Studies

University of Minnesota

321 19th Ave S, 3-300

Minneapolis, MN 55455

USA

E-mail: jbudd@umn.edu 
A central tenet of conflict resolution theory and practice in employment relations, the legal arena, and elsewhere has been that a voluntary settlement among disputants with a continuing relationship is better than an imposed one. The process of negotiation, perhaps assisted by mediation, is seen as allowing the participants to "craft individualized justice on their own terms based on their own interests and values” (Nolan-Haley 2012: 69). The parties to the resulting consensual agreement should, therefore, be more satisfied (Welsh 2001) and have stronger feelings of procedural justice and control over the process and outcomes (Shapiro and Brett 1993), which means that post-settlement compliance should be higher (Lipsky, Seeber, and Fincher 2003) and, in ongoing relationships, the relationship is expected to be more durable than when a settlement is imposed (Fuller 1971). Litigation, arbitration, and other non-consensual methods are important, but their ideal roles are to provide an incentive to reach a consensual agreement in order to avoid the uncertainty of an imposed settlement and to provide a final resolution when all else fails. As noted by Farber and Katz (1979: 55), "it is commonly thought that a good procedure is one that is seldom used and that provides an incentive for the parties to reach a negotiated settlement” (also, Chelius and Dworkin 1980). Indeed, the Ontario Labour Relations Board has explained that “the real labour-relations goal” of Ontario’s first contract arbitration statute "is to 'encourage' the parties to reach that initial collective bargaining agreement on their own, and not have the Board impose third-party determination" (Great Lakes Community Credit Union Limited [1991] OLRB Rep. June 758).

Yet there is little empirical evidence to indicate whether consensual agreements are better than imposed settlements. A lot of research compares mediation to arbitration and litigation (Wall and Dunne 2012; Wissler 2004), but it largely focuses on settlement rates, costs, and participant evaluations. Wall and Dunne's (2012) review article cites twelve studies claiming to 
show that mediation results in an improved relationship, but seven lack data and the other five lack a comparison group. Empirical evidence on compliance is also limited. McEwen and Maiman (1981) find that mediated settlements of small-claims disputes are significantly more likely to result in full payment than imposed, adjudicated settlements while Wissler (1995) finds no differences. So the empirical record shows that participants in a consensual rather than imposed dispute resolution process are more satisfied and report greater levels of fairness (e.g., Shapiro and Brett 1993), but there is a need for careful empirical analyses of the widely-held belief that post-settlement behaviors and outcomes will also be better.

This paper, then, uses data from Major League Baseball spanning 1988 to 2011 to test whether voluntarily-negotiated agreements produce better long-run relationships than third-party imposed settlements. Baseball players with between three (sometimes two) and six years of service are eligible for salary arbitration with their current team. In any given year, some go to arbitration while many settle voluntarily. If voluntarily-negotiated agreements are meaningfully better, then in the following season we would expect to see better on-field performance and more lasting relationships for those who reached a salary agreement voluntarily compared to those who went to arbitration. Analyzing these two propositions is the focus of this paper. Major League Baseball provides a compelling setting for these analyses because individual performance is well measured, the possibility of relationship breakdown is quite real, and both voluntary and imposed settlements are routinely used. The ramifications, however, extend beyond professional sports because a better understanding of the lasting effects of alternative dispute resolution methods can have important implications for how to best resolve bargaining impasses and grievances and how to design alternative dispute resolution (ADR) systems within organizations, the legal arena, social work, and elsewhere. 


\section{The Presumed Superiority of Voluntary Agreements}

The belief that a voluntary, consensual dispute resolution process is superior to a nonconsensual process that results in an imposed agreement is widespread. In the words of Dworkin (1997: 79), “anybody who knows anything about labor-management relations will tell you that the best settlement in any matter is one reached by the parties bilaterally, not one imposed by an arbitrator or government intervention.” In other areas, this sentiment might be most explicitly articulated in comparing mediation to arbitration or adjudication, but many of the perceived benefits of mediation are rooted in participation, voluntariness, and self-determination (NolanHaley 2012) — in contrast to the foundations of “authority and imposition of judgment” that underlie arbitration and adjudication (McEwen and Maiman 1981: 238) — and therefore extend to unassisted negotiations. ${ }^{1}$ It is widely assumed that parties involved in a dispute resolution method characterized by participation, voluntariness, and self-determination will be much more likely to be satisfied with this process than one that is non-consensual, and will view it as having higher degrees of procedural justice. Empirical analyses, such as Shapiro and Brett's (1993) comparison of unionized miners whose grievances were settled via mediation or arbitration, generally support this assumption (also, Brett, Barsness, and Goldberg 1996).

These higher levels of satisfaction and procedural justice, in turn, are believed to have positive effects that last beyond the immediacy of the settlement of the dispute. For example, Edwards (2009: 77) claims that meditation of child protection disputes

1 Mediation can have benefits beyond those present in unassisted negotiations because a mediator can help the negotiators with their relationship (Fuller 1971), but this is beyond the scope of this paper. On the hand, forms of legal mediation that are "less-than-voluntary, not-soconfidential, and adversarial” are more like arbitration than negotiation (Nolan-Haley 2012: 73). 
produces better, more detailed, nuanced, and longer-lasting results than litigated cases; it creates a problem-solving atmosphere in the court environment (an atmosphere that better serves all parties); it engages the parents in the decisionmaking process, thus making it more likely that they will follow any plan that they have helped draft.

In the context of workplace conflicts, Lipsky, Seeber, and Fincher (2003: 78) assert that "compliance with the eventual settlement is less likely to be a problem when the disputants have controlled the process that produced the outcome.” In their practical guide for resolving workplace conflicts, Cloke and Goldsmith (2000: 236) claim that "agreements reached in mediation face fewer enforcement problems because they are reached voluntarily.” However, no data or sources are provided to support this claim.

We translate these hypotheses about the lasting positive effects of voluntary, negotiated settlements over imposed ones into the context of salary arbitration in Major League Baseball. In particular, if greater satisfaction with a negotiated salary settlement than an arbitrated one has long run effects, we expect that players who avoided arbitration through a voluntary settlement will perform better than those whose dispute went all the way to arbitration. We also hypothesize that greater satisfaction by both the player and the club with a voluntary, negotiated settlement results in a stronger player-club relationship such that players who go to arbitration will be more likely to be released or traded than players who avoided arbitration.

In terms of the rhetorical emphasis on compliance with a negotiated agreement in the above quotes and elsewhere, we are not asserting that there will be problems with literal compliance in terms of not paying the imposed salaries. Rather, we can think of our hypotheses as a lack of full substantive compliance in that the players who experienced arbitration may not 
deliver full effort on the field and may not exhibit a positive attitude off the field while club management that experienced arbitration might seek to end the relationship. Note that these hypotheses are not comparisons between those who won arbitration and those who lost (Bretz and Thomas 1992; Hauenstein and Lord 1989; Mas 2006). Rather, we compare those who experienced arbitration—win or lose—with those who reached voluntary settlement instead. The (claimed) benefits of a consensual agreement derive from the nature of the process, not strictly from the specific terms of the outcomes. Superiority of a consensual dispute resolution process suggests that player performance may suffer even if a player wins his arbitration hearing and that the player-club relationship will be worsened regardless of which side wins the hearing owing to the adversarial nature of the process and the loss of control over the outcome. As argued by Tulis (2010: 92), voluntary agreements in baseball are important for maintaining a congenial relationship between the player and management. In an arbitration proceeding, the player would have to witness his team's management questioning his value to the team. As the player likely will remain on the team preserving a good relationship is of great importance.

Voluntary agreements can also promote an ongoing relationship by allowing players and clubs to reach agreements that the club believes are affordable. In 1974, Minnesota Twins pitcher Dick Woodson won the very first arbitration hearing but was traded to the richer New York Yankees less than three months later. In sum, "the risks of injury to the relationship between the club and its player from a salary arbitration hearing are immense” (Abrams 2000: 164).

On the other hand, we might not systematically observe these hypothesized differences. Even if participants to a consensual dispute resolution process are more satisfied with the process than those in a non-consensual process, this satisfaction might be short-lived or might not be 
strong enough to lead to changes in employee performance or relationship quality. Moreover, superiority of a consensual process is not universally accepted. During the rise of the alternative dispute resolution movement in the legal arena, Fiss (1984: 1075) famously argued against the presumed universal benefits of voluntary settlements because "justice may not be done.” A nonconsensual process also provides the opportunities for the negotiators to save face and pass the buck (McCall 1990). Indeed, in the U.S. unionized sector, grievance mediation is barely used while grievance arbitration is nearly universal suggesting that there are nuanced trade-offs between consensual and non-consensual processes (Feuille 1999). Furthermore, it is not necessarily the case that consensual processes are less adversarial than non-consensual processes. For example, in baseball arbitration hearings, players' "agents extol their virtues and their clubs present a litany of their failures” (Abrams 2000: 164), but the same might be true in their negotiations outside of the arbitration process. The benefits of a particular dispute resolution system, therefore, might depend on the particular characteristics of the dispute and the disputants rather than being universal (Wissler 1995). So more research is needed, especially research with comparison groups (Wall and Dunne 2012).

\section{Salary Arbitration in Major League Baseball}

Major League Baseball has used final-offer arbitration to resolve salary disputes between eligible players and clubs since 1974 (Abrams 2000; Dworkin 1981). Except in the earliest years that pre-dated free agency, arbitration has been available to players who have accumulated some years of service, but not enough years to qualify for free agency, which would allow them to sign with another club of their own choosing. The specific eligibility criteria and service definitions vary across successive collective bargaining agreements between the players union and the 
owners association, but arbitration is primarily available to out-of-contract players with at least three but less than six years of service. Before 1985 out-of-contract players with two years of service were also eligible, and since 1990 out-of-contract players with two years of service are also arbitration eligible if their playing time is among the top 17-22 percent of two-year players (the "Super Two rule"). Moreover, players with six or more years of service whose contracts are expiring (free agents) and their clubs can agree to arbitration as part of the re-negotiation process.

The typical scenario therefore involves a player with 3-5 years of service whose contract ended at the conclusion of the playing season in October. If the club wants to retain the player, the player and the club try to negotiate a new contract for one or more years. If these negotiations fail to result in a new agreement by early January, the player and the club can file for arbitration before a deadline specified by the collective bargaining agreement. Each side then has three days to exchange figures - that is, to specify their final salary demand (player) or offer (club) for the upcoming season. The only figure submitted, and the only issue to be decided by the arbitration panel, is the upcoming season's salary. Arbitration hearings then occur in early February. This is a final-offer arbitration procedure such that the arbitration panel must select either the player's or the club's figure. The format of the hearing (e.g., one hour for each side's initial presentation, half-hour for rebuttal), inadmissible evidence (e.g., the financial positions of the player and the club), and decision-making criteria (e.g., "the quality of the Player's contribution to his Club during the past season”) are specified by the collective bargaining agreement. Each side advocates for its final offer so the hearings are likely adversarial, including the player witnessing and rebutting the club's presentation as to why he's not worth what he's asking. After reaching its decision - usually within 24 hours of the hearing - the arbitration panel informs the player 
and the club as to which figure was selected. The arbitration panel enters this figure into a preexecuted contract that was submitted with a blank salary line by the player and the club, and the contract becomes binding. The club, however, can subsequently release or trade a player. As such, the player can switch teams only with his current club's consent.

At any time prior to the announcement of the arbitration panel's decision, the club and player can voluntarily agree to a new contract. So for each offseason's negotiation/arbitration round, there are five classes of players: 1) eligible for arbitration but avoided arbitration by reaching a new agreement before filing for arbitration, 2) filed for arbitration but negotiated a new agreement before exchanging salary figures, 3) filed for arbitration and exchanged salary figures but negotiated a new agreement before the arbitration hearing, 4) went to arbitration and the player won, and 5) went to arbitration and the player lost.

The public nature of the final-offer salary arbitration process in Major League Baseball, especially in being able to identify winners and losers, combined with extensive performance indicators makes this a popular setting for scholarly research. Some of this research focuses on the effects of the presence of the salary arbitration process. Chelius and Dworkin (1980), for example, find that the process encourages voluntary settlements. Kahn (1993) finds that eligibility for arbitration increases a player's salary. Other research examines the parties' behavior within the arbitration process, such as the parties' decision to file, their offers, and the arbitrators' decisions (Burger and Walter 2005; Burgess and Marburger 1993; Faurot and McAllister 1992; Fizel, Krautmann, and Hadley 2002).

Closest to our research are analyses of the effect of arbitration on subsequent player performance (Bretz and Thomas 1992; Hauenstein and Lord 1989). These analyses use equity theory to hypothesize that baseball players who win an arbitration hearing will perform better 
and be less likely to move teams than those who lose an arbitration hearing. Empirical comparisons of winners and losers support these hypotheses. This research supports ours in that the theorizing and empirical results are consistent with the existence of measurable behavioral reactions to the arbitration process. ${ }^{2}$ But note carefully that this previous research only focuses on players who go to arbitration and analyzes differences between winner and losers. Our research is rooted more in procedural justice than distributive justice, and we make fuller use of the different classes of players noted above to compare those who reach a consensual agreement to those who have an arbitrated settlement imposed.

\section{Data}

To analyze whether performance and relationship duration are systematically different for players who have a settlement imposed by arbitration compared to those who voluntarily agree to a new salary, we collected comprehensive performance and arbitration data for 1988-2011. Data on arbitration winners and losers goes back to 1974, but 1988 is the first year that we can reliably identify all of the players filing for arbitration. The primary sources for the data are the Biz of Baseball (bizofbaseball.com) and Lahman's Baseball Database (www.seanlahman.com/baseballarchive/statistics/), supplemented by data from the official Major League Baseball website and various media reports.

Each observation in the data set is a player who filed for arbitration between 1988 and 2011. The data include pitchers and position players. The arbitration process occurs during January and February so the year of the arbitration filing is also the year of the upcoming

\footnotetext{
${ }^{2}$ More generally, Stadler (2007) documents the wide-ranging psychological aspects of baseball performance which further reinforces the utility of analyzing post-arbitration performance and relationship duration.
} 
baseball season that generally runs from April through October. We only include players in three of the five classes listed above: 1) exchanged salary figures but negotiated a new agreement before the arbitration hearing, 2) won in arbitration, or 3) lost in arbitration. These are the negotiating pairs that went through all of the steps to get to arbitration and we focus our analyses in this way in order to reduce the unobservable differences across observations. In other words, by excluding pairs that settled earlier in the process, we are trying to make the sample as homogeneous as possible.

Table 1 shows the frequency of each category by year. There are 1,424 cases with complete data across the 24-year time span. In recent years, the numbers of post-exchange settlements and arbitration hearings have declined. Overall, 83 percent of the pairs that exchanged offers settled on a new contract before arbitration; the remainder went to arbitration with clubs winning about two-thirds of the hearings.

In order to analyze whether there are post-settlement performance differences across these categories, we merged performance statistics for each player for the season that immediately follows the arbitration process. As key measures of performance, we use earned run average (ERA) for pitchers and we use batting average for position players. These are the most widely-used statistics for pitching and hitting performance, respectively. A pitcher's ERA indicates the average number earned runs allowed per nine innings pitched. A batter's batting average is the fraction of official at-bats in which the player gets a hit. Both have been used for more than 100 years and are widely discussed by analysts, the media, and fans. As a robustness check, we also use a more sophisticated performance measure from the sabermetrics movement (James 1985). For pitchers, we use the defense-independent ERA that only uses events that are 
solely within the pitcher's control. For batters, we use runs created which was devised because a batter's job is ultimately to create runs, not hits per se.

For comparability across pitchers and hitters, each measure is converted into a standardized measure with mean zero and standard deviation one within each season and league using most players, not just the 1,424 players in the arbitration sample. ${ }^{3}$ Our key performance measure is therefore a pooled measure that includes standardized ERA and batting average. A value of 0.50 , for example, indicates that a player's performance was 0.50 standard deviations above the mean for that metric in that year with positive values indicating better performance. ${ }^{4}$ The sabermetrics measure used in robustness checks was created in the same manner and combines reverse-coded standardized defense-independent ERA and standardized runs created. Summary statistics for these two measures are presented in Table 2. We also use the previous two season's values of these same performance measures to control for player quality. All performance measures are for each player's entire season irrespective of the number of teams he played on. ${ }^{5}$

In addition to performance, we also analyze whether the durability of the player-club relationship systematically differs by settlement type. To do this, we construct two measures. First, we create a variable that indicates if a player was traded or released before the start of the season. Second, we create a similar variable that captures whether a player was traded or released before the end of the season, including pre-season trades and releases. In other words,

\footnotetext{
3 To remove artificially high and low values, we exclude batters with fewer than 50 at bats and pitchers with fewer than 50 outs pitched when calculating the means and standard deviation by season that are used to create standardized measures of performance.

${ }^{4}$ After standardization, the pitching performance variable is multiplied by -1 to correct for the fact that a lower ERA indicates fewer runs conceded and therefore a stronger pitching performance.

${ }^{5}$ Limiting the performance analyses to each player's performance solely with his arbitration team does not change the results.
} 
the first variable reflects players who are not with their arbitration club at the start of the regular season that immediately follows the arbitration process while the second variable reflects players who are not with their arbitration club at the end of the regular season following the arbitration process. In our sample, 2.7 percent are traded or released before the season starts and 12.9 percent are traded or released before the season ends.

Summary statistics for additional control variables are also presented in Table 2. This includes number of prior years played, whether the player was born in the United States, and the player's age. For pitchers, we also control for whether he pitches left- or right-handed, and for batters, we control for whether he bats left, right, or is a switch hitter. Club and year effects will be included in the multivariate models to control for club-specific and year-specific influences. Lastly, we also observe the player's salary demand, the club's final offer, and the subsequent agreed-upon or imposed salary. We use this information to construct the three variables on disagreement and settlement compromise that are shown in the last three rows of Table 2. These variables will be described in more detail later in the paper.

\section{Does Arbitration Affect Subsequent On-Field Performance?}

If the oft-assumed benefits of a voluntary dispute resolution process were strong and lasting, then baseball players who settle their salary disputes prior to an arbitration hearing would perform better in the next season compared to those who have a new salary imposed by an arbitration award, ceteris paribus. To analyze this, we estimate regression models in which player performance for the season following the arbitration process is the dependent variable. The primary independent variables of interest are dummy variables that indicate that the player and club went to arbitration. The results will be reported with two primary specifications-one in 
which separate dummy variables are included for arbitration winners and arbitration losers, and an alternative specification in which a single dummy variable indicates that the dispute went to arbitration. The former specification allows the relationship between performance and arbitration to differ between winning and losing; the latter specification more directly tests the hypothesis that a non-consensual process, irrespective of winning or losing, is different from a consensual settlement. Recall that the data set only includes those who filed for arbitration and exchanged salary offers, so the comparison group consists of those who filed for arbitration and settled after exchanging salary figures. Players ineligible for arbitration, already under contract, settling prior to filing for arbitration, or settling before exchanging offers in the arbitration process are excluded from the data.

Table 3 reports the regression results for using standardized performance as the dependent variable. Recall that this standardized performance measure is derived from each pitcher's ERA and each position player's batting average. Columns 1-3 include separate variables for arbitration winners and losers, but with varying levels of control variables to account for player quality and other influences on performance. In column 1, the control variables are player characteristics as well as fixed year and team effects; column 2 adds the player's standardized performance for the previous two seasons; column three adds team-by-year interactions. By construction, positive values of the dependent variable reflect better levels of performance-a higher batting average or a lower ERA—so the statistically-significant, negative coefficient for the player losing arbitration in column 1 indicates that such players perform worse (a lower batting average or a higher ERA) compared to those who settle voluntarily in the step prior to arbitration, though the effect is only marginally statistically significant after controlling for prior performance (column 2). The negative estimate for arbitration winners in column 1 
suggests that arbitration winners perform worse, but this effect is not statistically significant and it varies depending upon the control variables included. Column 3 adds team-by-year effects which absorb many degrees of freedom, so the estimates become noisier, and the estimate for arbitration winners is no longer negative.

The penultimate row on Table 3 presents the p-values from a test for the equality of two arbitration estimates; given the imprecise estimates, it is not surprising that we cannot reject that these coefficients are the same at conventional levels of significance. Columns 4-6 therefore report the results of repeating the regressions reported in columns 1-3 with the two arbitration variables replaced by a single variable that indicates that the player's salary dispute was resolved by an arbitration hearing. In each of the models, the point estimate is negative- that is, players who go to arbitration perform worse afterwards compared to players who filed for arbitration and exchanged offers but settled. This estimate is statistically significant in column 4 , but not when controlling for lagged performance (column 5) and team-by-year effects (column 6). The models in Table 3, therefore, provide, at best, weak evidence that players who experienced arbitration performed worse than those who settled voluntarily immediately prior to a hearing. Rather, the significant results appear driven by arbitration losers so if there is a negative performance effect, it appears more likely to reflect player dissatisfaction with losing rather than dissatisfaction with a non-consensual process.

Table 4 reports the results of a series of robustness checks. The columns in Table 4 follow the same specifications as the columns in Table 3, but only the results for the key arbitration variables are reported. The first three rows in Table 4 repeat the key results from Table 3 for ease of comparison. One might question whether very experienced free agents who end up in arbitration and the Super-Twos are different from the players who are normally 
covered by the arbitration process. The second three-row block of Table 4 therefore repeats the analyses for the subsample of players with between three and seven years of service. Given that this captures 93 percent of the sample, it is unsurprising that the results are qualitatively similar to the baseline results.

One might also think that if there is dissatisfaction with the arbitration process that carries over to the season that this would be most likely to be evident at the beginning of the season. So the next two blocks of Table 4 reports the analyses for the first (April) and second (May) months of the season. Many of the estimates are negative, including the estimates for arbitration winners in May, but the estimates are imprecisely-estimated and therefore lack statistical significance. As an additional check, the next block of Table 4 uses a sabermetric rather than traditional performance measure that combines reverse-coded standardized defense-independent ERA and standardized runs created. The qualitative pattern of results follows a similar pattern to the baseline results, though the magnitude of the estimates are smaller and none are statistically significant.

The results reported to this point compare players who went to arbitration with those who avoided arbitration in the immediately-preceding step-that is, after exchanging salary offers. We can also comprehensively identify players who filed for arbitration and settled before exchanging. The last block in Table 4, therefore, expands the comparison category to include all those who settled after filing for arbitration, irrespective of whether they exchanged salary offers. The pattern of results is similar to the baseline results. Specifically, the coefficients for players losing arbitration are negative and of meaningful magnitude, though statistically insignificant, the coefficients for arbitration winners are much smaller (in absolute value) and very imprecisely estimated (columns 1-3), and the coefficients for those who went to arbitration (columns 4-6) 
follow the pattern of the arbitration losers coefficients, but are smaller and also not statistically significant.

So these robustness results do little to alter the conclusion derived from the baseline result that there is, at best, weak evidence that baseball players who experienced arbitration performed significantly differently from those who exchanged arbitration offers but settled voluntarily. In other words, the results fails to produce evidence of strong performance effects of imposed outcome compared to voluntary agreement.

\section{Does Arbitration Affect Relationship Durability?}

Proponents of voluntary dispute resolution procedures also assert that such procedures will promote a stronger relationship between the parties. We test this by analyzing whether relationship durability is systematically different for players who have a settlement imposed by arbitration compared to those who voluntarily agree to a new salary. In other words, are players who arbitrated more likely to change teams than players who settled after filing for arbitration? To address this, we estimate linear probability models where the dichotomous dependent variable equals 1 if the player is with a team different from his arbitration club when the season following the arbitration process ends, and 0 otherwise. The independent variables are the same as in the player performance models.

The results for the baseline specifications are reported in Table 5. The estimates in column 1 indicate that, on average, a player who loses an arbitration hearing is 7.8 percentage points more likely to be released or traded before the end of the season than a player who settles voluntary. Moreover, a player who wins an arbitration hearing is also more likely to be released or traded—on average, by 14.9 percentage points. Both of these estimates are statistically 
significant at conventional levels. In terms of practical significance, the probability of a relationship break-up among those who settled voluntarily is 11 percent. So the results in column 1 indicate that losing arbitration increases the likelihood of relationship break-up by roughly 70 percent while winning arbitration increases it by 135 percent. The results are robust to controlling for player quality via the addition of two lagged years of prior performance (column 2), and is essentially robust to the inclusion of team×year interactions (column 3). ${ }^{6}$

Moreover, a simple t-test fails to reject the null hypothesis that the arbitration losing and winning coefficients are statistically different from each other so the specifications reported in columns 4-6 compare those who went to arbitration with those who settled voluntarily. The results are what one would expect given the results in columns 1-3-that is, positive and statistically significant estimates in all three specifications. The estimates imply that controlling for a variety of characteristics, the relationship between a player and a club that have an arbitration settlement imposed upon them is, on average, twice as likely to end before the end of the season compared to a relationship that settles voluntarily in the step prior to arbitration.

The first robustness check in Table 6 is to confirm that we obtain the same results using probit estimation that formally models the dichotomous nature of the dependent variable. The probit estimates, which have been converted to marginal effects in Table 6, are positive and statistically significant. Given the overall similarity, we use linear probability models for the remainder of our estimations. ${ }^{7}$ The next robustness check limits the sample to players with 3-7 years of service. The coefficients are uniformly slightly smaller. While the coefficients for

\footnotetext{
${ }^{6}$ While the losing arbitration coefficient in column 3 is technically not significant at the five percent level, its p-value is only 0.054 .

${ }^{7}$ The magnitudes of the coefficients in columns 3 and 6 are somewhat different. This is because the sample composition changes because many of the team $\times$ year effects perfectly predict the dependent variable and observations in these cells are excluded from the probit estimation.
} 
arbitration losers are not statistically significant at conventional levels, the overall pattern is quite similar, including statistically significant, positive estimates for those going to arbitration (columns 4-6). As an alternative measure of relationship stability, we look at whether a player is with a new team at the start rather than end of the first season following the arbitration process. The next block of results in Table 6 shows that these results are very similar to the results for switching by the end of the season. In effect, these estimates are even larger than in the baseline specification because only 1.6 percent of the consensual settlement players are released or traded before the start of the season. So the estimates in columns 4-6 imply that the likelihood of a preseason break-up is approximately four times larger when a settlement is imposed. Lastly, the results are also unchanged when the comparison group is expanded to include those who settled after filing for arbitration but before exchanging offers.

These are important results on relationship deterioration. It is typical to assume that good things will come from winning a dispute, but this result reminds us that in final-offer arbitration, there is always a loser. In other words, these results indicate that when the player loses, he is significantly less likely to stay with that club, and when the club loses, the player is significantly less likely to be retained by the club. Consequently, in this setting for these types of players, it appears that a consensual resolution does have the benefits often claimed.

\section{The Intensity of the Dispute and the Margin of Victory}

The analyses to this point have focused on the stage of the salary arbitration process in Major League Baseball that results in a new salary. In effect, these analyses uncover the average effect of settlement stage across negotiations and disputes that have different intensities and varying degrees of compromise in the resulting salary. In a final set of analyses we explore 
whether the intensity of the dispute and the margin of victory are significantly related to subsequent player performance and relationship durability or alter the relationship between these outcomes and settlement stage. To do this, recall that our data consists of player-club pairs that exchanged offers so we are able to use three salary figures: the club's offered salary, the player's demanded salary, and the actual salary that results from the process. Recall further that the actual salary results from consensual negotiations 83 percent of the time, the player losing arbitration 10 percent of the time, and the player winning arbitration 7 percent of the time.

It can be difficult to observe the intensity of a dispute, but it seems reasonable to believe that it will be related to the divergence between what the club offers and the player demands. That is, disputes with a larger gap are expected to typically be more intense. To formalize this, we create a salary disagreement measure which is the difference between the player's demand and the club's offer expressed as a fraction of the average of the two offers. For example, in a 2010 case, Angels catcher Jeff Mathis requested a new salary of \$1.3 million whereas the club offered $\$ 700,000$. Our disagreement measures this $\$ 600,000$ difference given a $\$ 1$ million average offer, as 0.60. In that same round, Angels pitcher Joe Saunders requested \$3.85 million while the club offered $\$ 3.6$ million. This is a $\$ 250,000$ difference relative to an average of \$3.725—-that is, a disagreement of only 0.067. We assume that, on average, differences like the Mathis case reflect more intense disputes than differences like the Saunders case. ${ }^{8}$

Tables 7-8 report the results of augmenting the player performance and relationship break-up regression models with this salary disagreement measure. All of these results use the

\footnotetext{
${ }^{8}$ Indeed, in these particular cases, Mathis went to arbitration (and lost) whereas Saunders and the Angels settled prior to the hearing. To look at this more systematically, we estimated a regression with going to arbitration as the dependent variable and using the same controls as in column 5 in the previous tables as well as the disagreement measure. Disagreement is positively related to the likelihood of arbitration (p-value 0.002).
} 
specification from the earlier tables that include the demographic controls, lagged performance, and years played, team, and, year effects. Columns 1 and 4 in each of these tables reports a baseline specifications for ease of comparison. Columns 2 and 5 in Tables 7-8 add the salary disagreement variable to each model to assess whether controlling for this proxy of dispute intensity alters the earlier results. While the negative performance effect of losing in arbitration is dampened slightly, the overall pattern of results is unchanged. Interestingly, however, higher levels of salary disagreement are associated with lower performance. Lastly, columns 3 and 6 of Tables 7-8 add interactions between the disagreement and the arbitration variables to see if the arbitration effects are impacted by the intensity of the dispute. None of the interaction terms are statistically significant.

Finally, we also use the salary data to construct measures of the degree of compromise and victory in the final settlement. Specifically, we create a variable that measures the player's new salary as fraction of the player's final offer and a variable that indicates the player's new salary as fraction of club's final offer. Returning to the examples above, the arbitration panel ruled in favor of Mathis. His salary as a fraction of what he demanded is therefore 1. From the club’s perspective, however, his new salary of $\$ 1.3$ million is 1.857 times their final offer. In contrast, after exchanging salary offers, Saunders and his club avoided arbitration by agreeing to a new salary of $\$ 3.7$ million. From the player's perspective, this represents 0.961 of his demand; from the club's perspective, this represents 1.028 of its offer.

One might think that the player's margin of victory will affect subsequent performancethat is, the larger the margin of victory, the greater satisfaction and therefore a larger performance increase. To analyze this, we start with the baseline performance regression using the demographic controls, lagged performance, and years played, team, and year effects as 
reported in column 1 of Table 7. To this model we add the player's new salary as a fraction of the player's final offer. The estimated coefficient for this variable is significantly positive (column 1 in Table 9) which indicates that the better the player did in the salary determination process, the better he performed in the subsequent season. Interestingly, controlling for this salary outcome also makes the coefficients for losing and winning arbitration both negative and of similar magnitude, but neither are statistically significant. Column 2 in Table 9 adds an interaction between the salary settlement from the player's perspective and an indicator that the player lost his arbitration hearing. ${ }^{9}$ The interaction, however, is estimated to be essentially zero.

Lastly, columns 3 and 4 of Table 9 analyze the relationship between the margin of victory (or defeat) and whether the player-club relationship breaks-up. In column 3, the player's new salary as fraction of player's final offer and as a fraction of the club's final offer are added to the baseline specification. Comparing these results to those reported in column 1 of Table 8 indicates that controlling for these additional variables does not change the qualitative pattern of the results. That is, going to arbitration has negative consequences for relationship durability, even after controlling for how well or poorly the player and club fared in the final salary outcome relative to their demand.

But perhaps the effect of arbitration varies by the extent to which the player or club feel that they did well in the final outcome. So column 4 of Table 9 adds interactions. If a player loses in arbitration, we expect that the player-club relationship might be weakened by player frustration, and that this would be stronger the worse the player fares in terms of final salary. So we interact a player loss with the settlement as a fraction of the player's demand. If a player wins

${ }^{9}$ Column 2 does not include an interaction with the player winning arbitration because the settlement as a fraction of the player's final offer is always one when the player wins. Also, because columns 1 and 2 analyze player performance, the salary settlement as a fraction of the club's offer is excluded. 
in arbitration, we expect that the relationship might be more likely to end the more expensive the settlement is from the club's perspective. So we interact a player victory with the settlement as a fraction of the club's demand. None of the interactions are significant.

\section{Conclusions}

Many dispute resolution researchers and practitioners believe that dispute resolution procedures that result in consensual, negotiated agreements, perhaps assisted by mediation, are better than procedures such as arbitration and litigation that impose an agreement upon the disputants. Though it seems logical that parties would be more likely to abide by an agreement they voluntary consented to and that such relationships would be more lasting, this might not always be the case. For example, if an arbitration or court hearing is seen as more fair by one of the disputants then the benefits might be reversed. So what happens in practice? Beyond measures of satisfaction with the dispute resolution procedure, systematic evidence on more lasting and important effects comparing real-world outcomes that result from actual behavior across alternative dispute resolution procedures is scant.

This paper therefore analyzes over 1,400 salary re-negotiations from Major League Baseball between 1988 and 2011 to examine whether negotiated or arbitrated settlements are associated with differential levels of subsequent player performance and player-club relationship durability. With respect to player performance, the evidence suggests that only one conclusion can be stated confidently: experiencing final-offer arbitration does not substantially improve performance relative to settling voluntarily just prior to an arbitration hearing. But does arbitration reduce performance? In some specifications, a consensual negotiated settlement is associated with higher performance, but this result is not very robust. So there is not sufficient 
evidence to conclude that consensual, negotiated settlements are better than settlements imposed by arbitration with respect to subsequent player performance. Turning to relationship durability, the results are stronger. Specifically, players who experience arbitration-win or lose-are significantly less likely to still be with the arbitration team at the end of the season immediately following arbitration. Putting all of this together, then, leads us to conclude that there is some support for the conventional wisdom (consensual agreements improve relationship quality), but not as robust as the conventional wisdom would predict (little effect on performance).

The mixed support for the claimed superiority of voluntary dispute resolution procedures is further clouded by the possibility that ending up in arbitration is an endogenous event. We have controlled for prior performance and other observable or fixed effects, but in some cases there might be unobservable, idiosyncratic factors that lead to the deterioration of the relationship and also to arbitration. In such cases, arbitration reflects rather than causes relationship quality and durability. We are unable to formally estimate an endogenous model due to a lack of good identifying instruments and so it is possible that even the evidence that seemingly supports the conventional wisdom actually reflects some unobservable set of factors surrounding the nature of the disputants' relationship. However, recall that we have restricted our analyses to only those player-club pairs that went all the way to exchanging offers in order to make the arbitration and non-arbitration observations as similar as possible. Moreover, adding important independent variables, such as prior performance, club fixed effects and disagreement intensity, to the models do not change results. But even if our strategies for addressing endogeneity are imperfect, the results are nevertheless important for revealing an association between how disputes are resolved and relationship durability that is worthy of further study. 
While the data come from the context of professional baseball, these results are important for dispute resolution researchers and practitioners with implications beyond professional baseball. The claimed superiority of voluntary dispute resolution procedures is neither uniformly rejected nor supported. Additional research and perhaps some re-thinking of longstanding assumptions are therefore needed. This includes questioning whether voluntary methods are always superior as well as whether non-consensual methods provide the desired incentives for voluntary settlement. Additional research into these types of questions should follow this paper and find real-world settings in which there are observable performance measures, the possibility of relationship breakdown, and non-trivial use of both voluntary and imposed settlement procedures. Moreover, the intensity of a dispute and the margin of victory can be difficult to measure in real-world disputes. The final offer process used in Major League Baseball provides a unique opportunity to assess these issues. In this case, these factors did not change the arbitration results, which is itself an important result, though they do seem associated with subsequent performance. So elements of both distributive and procedural are important in some of the results.

Lastly, to the extent that the results suggest that, at least in some cases, the nature of the dispute resolution process affects subsequent outcomes, then organizational dispute resolution systems need to be designed in ways that support rather than undermine other organizational objectives (Reuben 2005). In designing these systems, and in the research that underlies this, it is easy to focus on employee reactions to winning, losing, and perceived injustice. But these analyses remind us that the employment relationship is two-sided. In final-offer arbitration, especially, every winner has a loser such that players are less likely to remain with their team when they lose and when they win — that is, when the organization loses. We therefore need to be 
careful not to overlook the reactions of managers and organizational leaders. These reactions are equally important in determining the conditions under which voluntary dispute resolution procedures are superior to imposed settlement procedures. 


\section{References}

Abrams, Roger I. (2000) The Money Pitch: Baseball Free Agency and Salary Arbitration (Philadelphia: Temple University Press).

Brett, Jeanne M., Zoe I. Barsness, and Stephen B. Goldberg (1996) “The Effectiveness of Mediation: An Independent Analysis of Cases Handled by Four Major Service Providers,” Negotiation Journal, vol. 12, no. 3 (July): 259-69.

Bretz, Robert D., Jr., and Steven L. Thomas (1992) "Perceived Equity, Motivation, and FinalOffer Arbitration in Major League Baseball,” Journal of Applied Psychology, vol. 77, no. 3 (June): 280-87.

Burger, John D., and Stephen J. K. Walters (2005) “Arbitrator Bias and Self-Interest: Lessons from the Baseball Labor Market,” Journal of Labor Research, vol. 26, no. 2 (Spring): 267-80.

Burgess, Paul L., and Daniel R. Marburger (1993) "Do Negotiated and Arbitrated Salaries Differ under Final-Offer Arbitration?” Industrial and Labor Relations Review, vol. 46, no. 3 (April): 548-59.

Chelius, James R., and James B. Dworkin (1980) “An Economic Analysis of Final-Offer Arbitration as a Conflict Resolution Device,” Journal of Conflict Resolution, vol. 24, no. 2 (June): 293-310.

Cloke, Kenneth and Joan Goldsmith (2000) Resolving Conflicts at Work: A Complete Guide for Everyone on the Job (San Francisco: Jossey-Bass).

Dworkin, James B. (1981) Owners Versus Players: Baseball and Collective Bargaining (Boston: Auburn House).

Dworkin, James B. (1997) "Final Offer Salary Arbitration (FOSA)—a.k.a. Franchise Owners' Self Annihilation,” Daniel R. Marburger (ed.), Stee-rike Four! What's Wrong with the Business of Baseball? (Westport, CT: Praeger): 73-83.

Edwards, Leonard (2009) “Child Protection Mediation: A 25-Year Perspective,” Family Court Review, vol. 47, no. 1 (January): 69-80.

Farber, Henry S., and Harry C. Katz (1979) "Interest Arbitration, Outcomes, and the Incentive to Bargain,” Industrial and Labor Relations Review, vol. 33, no. 1 (October): 55-63.

Faurot, David J., and Stephen McAllister (1992) "Salary Arbitration and Pre-Arbitration Negotiation in Major League Baseball,” Industrial and Labor Relations Review, vol. 45, no. 4 (July): 697-710. 
Feuille, Peter (1999) “Grievance Mediation,” in Adrienne E. Eaton and Jeffrey H. Keefe (eds.), Employment Dispute Resolution and Worker Rights in the Changing Workplace (Champaign, IL: Industrial Relations Research Association): 187-217.

Fiss, Owen M. (1984) “Against Settlement,” Yale Law Journal, vol. 93, no. 6 (May): 1073-90.

Fizel, John, Anthony C. Krautmann, and Lawrence Hadley (2002) "Equity and Arbitration in Major League Baseball,” Managerial and Decision Economics, vol. 23, no. 7 (OctoberNovember): pp. 427-35.

Fuller, Lon L. (1971) "Mediation-Its Forms and Functions," Southern California Law Review, vol. 44, no. 2 (Winter): 305-39.

Hauenstein, Neil M. A., and Robert G. Lord (1989) "The Effects of Final-Offer Arbitration on the Performance of Major League Baseball Players: A Test of Equity Theory,” Human Performance, vol. 2, no. 3: 147-65.

James, Bill (1985) The Bill James Historical Baseball Abstract (New York: Villard Books).

Kahn, Lawrence M. (1993) "Free Agency, Long-Term Contracts and Compensation in Major League Baseball: Estimates from Panel Data," Review of Economics and Statistics, vol. 75, no. 1 (February): 157-64.

Lipsky, David B., Ronald L. Seeber, and Richard D. Fincher (2003) Emerging Systems for Managing Workplace Conflict: Lessons from American Corporations for Managers and Dispute Resolution Professionals (San Francisco: Jossey-Bass).

Mas, Alexandre. (2006) "Pay, Reference Points, and Police Performance," Quarterly Journal of Economics, vol. 71, no. 3 (August): 783-821.

McCall, Brian P. (1990) "Interest Arbitration and the Incentive to Bargain: A Principal-Agent Approach,” Journal of Conflict Resolution, vol. 34, no. 1 (March): 151-67.

McEwen, Craig A., and Richard J. Maiman (1981) "Small Claims Mediation in Maine: An Empirical Assessment,” Maine Law Review, vol. 33: 237-68.

Nolan-Haley, Jacqueline (2012) "Mediation: The 'New Arbitration," Harvard Negotiation Law Review, vol. 17 (Spring): 61-95.

Reuben, Richard C. (2005) "Democracy and Dispute Resolution: Systems Design and the New Workplace, Harvard Negotiation Law Review, vol. 10 (Spring): 11-68.

Shapiro, Debra L., and Jeanne M. Brett (1993) "Comparing Three Processes Underlying Judgments of Procedural Justice: A Field Study of Mediation and Arbitration,” Journal of Personality and Social Psychology, vol. 65, no. 6 (December): 1167-77. 
Stadler, Mike (2007) The Psychology of Baseball: Inside the Mental Game of the Major League Player (New York: Penguin).

Tulis, Benjamin A. (2010) "Final-Offer 'Baseball' Arbitration: Contexts, Mechanics and Applications,” Seton Hall Journal of Sports and Entertainment Law, vol. 20, no. 1: 85130.

Wall, James A., and Timothy C. Dunne (2012) "Mediation Research: A Current Review," Negotiation Journal, vol. 28, no. 2 (April): 217-44.

Welsh, Nancy A. (2001) "The Thinning Vision of Self-Determination in Court-Connected Mediation: The Inevitable Price of Institutionalization?” Harvard Negotiation Law Review, vol. 6 (Spring): 1-96.

Wissler, Roselle L. (1995) "Mediation and Adjudication in the Small Claims Court: The Effects of Process and Case Characteristics," Law and Society Review, vol. 29, no. 2: 323-58.

Wissler, Roselle L. (2004) "The Effectiveness of Court-Connected Dispute Resolution in Civil Cases,” Conflict Resolution Quarterly, vol. 22, no. 1-2 (Fall-Winter): 55-88. 
Table 1: Counts of Arbitration Process Outcomes by Year

\begin{tabular}{|c|c|c|c|c|}
\hline Year & $\begin{array}{c}\text { Exchanged figures } \\
\text { but avoided by } \\
\text { settling } \\
\text { (1) }\end{array}$ & $\begin{array}{l}\text { Player lost } \\
\text { arbitration } \\
\text { hearing } \\
\text { (2) }\end{array}$ & $\begin{array}{c}\text { Player won } \\
\text { arbitration } \\
\text { hearing } \\
\text { (3) }\end{array}$ & $\begin{array}{c}\text { Total } \\
(4)\end{array}$ \\
\hline 1988 & 65 & 10 & 7 & 82 \\
\hline 1989 & 80 & 5 & 7 & 92 \\
\hline 1990 & 97 & 10 & 13 & 120 \\
\hline 1991 & 96 & 11 & 6 & 113 \\
\hline 1992 & 102 & 11 & 9 & 122 \\
\hline 1993 & 73 & 12 & 6 & 91 \\
\hline 1994 & 54 & 9 & 5 & 68 \\
\hline 1995 & 31 & 6 & 2 & 39 \\
\hline 1996 & 44 & 2 & 7 & 53 \\
\hline 1997 & 42 & 4 & 1 & 47 \\
\hline 1998 & 47 & 5 & 3 & 55 \\
\hline 1999 & 26 & 9 & 2 & 37 \\
\hline 2000 & 41 & 6 & 4 & 51 \\
\hline 2001 & 47 & 8 & 6 & 61 \\
\hline 2002 & 27 & 4 & 1 & 32 \\
\hline 2003 & 25 & 5 & 2 & 32 \\
\hline 2004 & 20 & 4 & 2 & 26 \\
\hline 2005 & 35 & 2 & 1 & 38 \\
\hline 2006 & 38 & 4 & 2 & 44 \\
\hline 2007 & 46 & 4 & 3 & 53 \\
\hline 2008 & 40 & 6 & 2 & 48 \\
\hline 2009 & 41 & 1 & 2 & 44 \\
\hline 2010 & 35 & 5 & 3 & 43 \\
\hline 2011 & 30 & 1 & 2 & 33 \\
\hline Total & 1,182 & 144 & 98 & 1,424 \\
\hline
\end{tabular}


Table 2: Summary Statistics of the Major League Baseball Player Arbitration Data, 1988-2011

\begin{tabular}{lc}
\hline & Means/Standard \\
& Deviations \\
\hline 1 if exchanged figures but avoided & 0.830 \\
arbitration by settling & $(0.376)$ \\
1 if player lost arbitration hearing & 0.101 \\
& $(0.302)$ \\
1 if player won arbitration hearing & 0.069 \\
& $(0.253)$ \\
Performance (batting average for hitters, earned run average for & 0.116 \\
pitchers), standardized among regular players in a season & $(1.146)$ \\
Sabermetrics performance (runs created for hitters, defense- & 0.195 \\
independent earned run average for pitchers), standardized among & $(1.124)$ \\
regular players in a season & \\
1 if traded or released before season start & 0.027 \\
& $(0.163)$ \\
1 if traded or released before season end & 0.129 \\
Prior years played & $(0.334)$ \\
1 if U.S. born & 5.349 \\
Age & $(1.945)$ \\
Left-handed pitcher & 0.784 \\
Right-handed pitcher & $(0.411)$ \\
Left-handed hitter & 28.980 \\
Right-handed hitter & $(2.554)$ \\
Switch-hitter & 0.134 \\
Salary disagreement (difference in exchanged offers as fraction of & $(0.341)$ \\
Salary settlement as a fraction of player's final offer(n=1,423) & 0.343 \\
Salary settlement as a fraction of club’s final offer (n=1,423) & $(0.475)$ \\
Sample size & 0.148 \\
& $(0.355)$ \\
& 0.284 \\
& $0.451)$ \\
& 0.091 \\
& $0.288)$ \\
& $0.134)$ \\
& 0.839 \\
& $1.173)$ \\
& $(0.180)$ \\
& 1,424 \\
\hline
\end{tabular}


Table 3: Performance and Salary Arbitration

\begin{tabular}{|c|c|c|c|c|c|c|}
\hline & \multicolumn{3}{|c|}{$\begin{array}{l}\text { Allowing for Differential } \\
\text { Win/Lose Arb. Effects }\end{array}$} & \multicolumn{3}{|c|}{$\begin{array}{l}\text { Pooling Arbitration } \\
\text { Winners and Losers }\end{array}$} \\
\hline & (1) & (2) & (3) & (4) & (5) & (6) \\
\hline $\begin{array}{l}\text { Player lost } \\
\text { arbitration }\end{array}$ & $\begin{array}{l}-0.244^{*} \\
(0.110)\end{array}$ & $\begin{array}{l}-0.195 \\
(0.104)\end{array}$ & $\begin{array}{l}-0.120 \\
(0.138)\end{array}$ & --- & --- & --- \\
\hline $\begin{array}{l}\text { Player won } \\
\text { arbitration }\end{array}$ & $\begin{array}{l}-0.040 \\
(0.103)\end{array}$ & $\begin{array}{l}-0.001 \\
(0.096)\end{array}$ & $\begin{array}{c}0.094 \\
(0.143)\end{array}$ & --- & --- & --- \\
\hline $\begin{array}{l}\text { Player went to } \\
\text { arbitration }\end{array}$ & --- & --- & --- & $\begin{array}{l}-0.161^{*} \\
(0.079)\end{array}$ & $\begin{array}{l}-0.116 \\
(0.074)\end{array}$ & $\begin{array}{l}-0.033 \\
(0.101)\end{array}$ \\
\hline Age & $\begin{array}{c}-0.539 * * \\
(0.156)\end{array}$ & $\begin{array}{c}-0.452 * * \\
(0.133)\end{array}$ & $\begin{array}{l}-0.403^{*} \\
(0.192)\end{array}$ & $\begin{array}{l}-0.548^{* *} \\
(0.156)\end{array}$ & $\begin{array}{c}-0.460^{* *} \\
(0.132)\end{array}$ & $\begin{array}{l}-0.413^{*} \\
(0.192)\end{array}$ \\
\hline Age squared & $\begin{array}{c}0.009 * * \\
(0.003)\end{array}$ & $\begin{array}{l}0.007^{* *} \\
(0.002)\end{array}$ & $\begin{array}{l}0.006^{*} \\
(0.003)\end{array}$ & $\begin{array}{c}0.009 * * \\
(0.003)\end{array}$ & $\begin{array}{l}0.007^{* *} \\
(0.002)\end{array}$ & $\begin{array}{l}0.006^{*} \\
(0.003)\end{array}$ \\
\hline $\begin{array}{l}\text { Left-handed } \\
\text { batter }\end{array}$ & $\begin{array}{l}0.190 * \\
(0.095)\end{array}$ & $\begin{array}{l}0.201 * \\
(0.081)\end{array}$ & $\begin{array}{l}0.252 * \\
(0.112)\end{array}$ & $\begin{array}{l}0.192 * \\
(0.096)\end{array}$ & $\begin{array}{l}0.204^{*} \\
(0.081)\end{array}$ & $\begin{array}{l}0.256^{*} \\
(0.111)\end{array}$ \\
\hline $\begin{array}{l}\text { Right-handed } \\
\text { batter }\end{array}$ & $\begin{array}{c}0.056 \\
(0.089)\end{array}$ & $\begin{array}{l}0.172 * \\
(0.080)\end{array}$ & $\begin{array}{c}0.121 \\
(0.110)\end{array}$ & $\begin{array}{c}0.062 \\
(0.089)\end{array}$ & $\begin{array}{l}0.177^{*} \\
(0.080)\end{array}$ & $\begin{array}{c}0.127 \\
(0.109)\end{array}$ \\
\hline $\begin{array}{l}\text { Switch-hitting } \\
\text { batter }\end{array}$ & $\begin{array}{c}0.115 \\
(0.121)\end{array}$ & $\begin{array}{c}0.139 \\
(0.108)\end{array}$ & $\begin{array}{c}0.175 \\
(0.135)\end{array}$ & $\begin{array}{c}0.119 \\
(0.121)\end{array}$ & $\begin{array}{c}0.142 \\
(0.109)\end{array}$ & $\begin{array}{c}0.177 \\
(0.135)\end{array}$ \\
\hline $\begin{array}{l}\text { Left-handed } \\
\text { pitcher }\end{array}$ & $\begin{array}{c}0.091 \\
(0.096)\end{array}$ & $\begin{array}{c}0.161 \\
(0.092)\end{array}$ & $\begin{array}{c}0.238 \\
(0.125)\end{array}$ & $\begin{array}{l}0.096 \\
(0.095)\end{array}$ & $\begin{array}{c}0.166 \\
(0.091)\end{array}$ & $\begin{array}{c}0.245 \\
(0.125)\end{array}$ \\
\hline U.S. born & $\begin{array}{c}0.033 \\
(0.094)\end{array}$ & $\begin{array}{c}0.069 \\
(0.087)\end{array}$ & $\begin{array}{c}0.135 \\
(0.131)\end{array}$ & $\begin{array}{c}0.040 \\
(0.094)\end{array}$ & $\begin{array}{c}0.075 \\
(0.086)\end{array}$ & $\begin{array}{c}0.140 \\
(0.130)\end{array}$ \\
\hline $\begin{array}{l}\text { Prior perf., } \\
\text { previous season }\end{array}$ & --- & $\begin{array}{l}0.352 * * \\
(0.044)\end{array}$ & $\begin{array}{l}0.324 * * \\
(0.054)\end{array}$ & --- & $\begin{array}{l}0.353^{* *} \\
(0.044)\end{array}$ & $\begin{array}{l}0.326 * * \\
(0.054)\end{array}$ \\
\hline $\begin{array}{l}\text { Prior perf., two } \\
\text { seasons previous }\end{array}$ & --- & $\begin{array}{l}0.221^{* *} \\
(0.044)\end{array}$ & $\begin{array}{l}0.215^{* *} \\
(0.055)\end{array}$ & --- & $\begin{array}{l}0.220^{* *} \\
(0.045)\end{array}$ & $\begin{array}{l}0.214^{* *} \\
(0.056)\end{array}$ \\
\hline $\begin{array}{l}\text { Years played, } \\
\text { year, and team } \\
\text { effects }\end{array}$ & Yes & Yes & Yes & Yes & Yes & Yes \\
\hline $\begin{array}{l}\text { Team×year } \\
\text { effects }\end{array}$ & No & No & Yes & No & No & Yes \\
\hline
\end{tabular}


Table 3 (continued)

\begin{tabular}{lcccccc}
\hline $\begin{array}{l}\text { p-value for } \\
\text { equality of player } \\
\text { lost and player }\end{array}$ & 0.167 & 0.164 & 0.275 & --- & --- & --- \\
$\begin{array}{l}\text { won } \\
\text { Adjusted } \mathrm{R}^{2}\end{array}$ & 0.045 & 0.144 & 0.086 & 0.044 & 0.144 & 0.086 \\
\hline
\end{tabular}

Notes: Each entry contains the estimated coefficient and robust standard error (in parentheses) from a regression model with dependent variable season-long earned run average (weighted across multiple stints where appropriate). Sample size is 1,424. Statistically significant at the * 0.05 or $* * 0.01$ level. 
Table 4: Performance and Salary Arbitration: Robustness Checks

\begin{tabular}{|c|c|c|c|c|c|c|}
\hline & \multicolumn{3}{|c|}{$\begin{array}{l}\text { Allowing for Differential } \\
\text { Win/Lose Arb. Effects }\end{array}$} & \multicolumn{3}{|c|}{$\begin{array}{l}\text { Pooling Arbitration } \\
\text { Winners and Losers }\end{array}$} \\
\hline & (1) & (2) & (3) & (4) & (5) & (6) \\
\hline \multicolumn{7}{|c|}{ Baseline results from Table $3(n=1,424)$} \\
\hline Player lost arbitration & $\begin{array}{l}-0.244^{*} \\
(0.110)\end{array}$ & $\begin{array}{l}-0.195 \\
(0.104)\end{array}$ & $\begin{array}{l}-0.120 \\
(0.138)\end{array}$ & --- & --- & --- \\
\hline Player won arbitration & $\begin{array}{l}-0.040 \\
(0.103)\end{array}$ & $\begin{array}{l}-0.001 \\
(0.096)\end{array}$ & $\begin{array}{c}0.094 \\
(0.143)\end{array}$ & --- & --- & --- \\
\hline Player went to arbitration & --- & --- & --- & $\begin{array}{l}-0.161^{*} \\
(0.079)\end{array}$ & $\begin{array}{l}-0.116 \\
(0.074)\end{array}$ & $\begin{array}{l}-0.033 \\
(0.101)\end{array}$ \\
\hline \multicolumn{7}{|c|}{ 3-7 years of service $(n=1,325)$} \\
\hline Player lost arbitration & $\begin{array}{c}-0.273^{*} \\
(0.116)\end{array}$ & $\begin{array}{l}-0.225^{*} \\
(0.109)\end{array}$ & $\begin{array}{l}-0.163 \\
(0.153)\end{array}$ & --- & --- & --- \\
\hline Player won arbitration & $\begin{array}{l}-0.011 \\
(0.107)\end{array}$ & $\begin{array}{c}0.011 \\
(0.099)\end{array}$ & $\begin{array}{c}0.086 \\
(0.142)\end{array}$ & --- & --- & --- \\
\hline Player went to arbitration & --- & --- & --- & $\begin{array}{l}-0.166 * \\
(0.084)\end{array}$ & $\begin{array}{l}-0.128 \\
(0.078)\end{array}$ & $\begin{array}{l}-0.063 \\
(0.109)\end{array}$ \\
\hline \multicolumn{7}{|l|}{ April only $(\mathrm{n}=1,375)$} \\
\hline Player lost arbitration & $\begin{array}{l}-0.100 \\
(0.097)\end{array}$ & $\begin{array}{l}-0.088 \\
(0.096)\end{array}$ & $\begin{array}{l}-0.007 \\
(0.122)\end{array}$ & --- & --- & --- \\
\hline Player won arbitration & $\begin{array}{c}0.042 \\
(0.092)\end{array}$ & $\begin{array}{c}0.062 \\
(0.092)\end{array}$ & $\begin{array}{c}0.005 \\
(0.130)\end{array}$ & --- & --- & --- \\
\hline Player went to arbitration & --- & --- & --- & $\begin{array}{l}-0.041 \\
(0.074)\end{array}$ & $\begin{array}{l}-0.026 \\
(0.074)\end{array}$ & $\begin{array}{l}-0.002 \\
(0.098)\end{array}$ \\
\hline \multicolumn{7}{|l|}{ May only $(\mathrm{n}=1,352)$} \\
\hline Player lost arbitration & $\begin{array}{l}-0.185 \\
(0.109)\end{array}$ & $\begin{array}{l}-0.169 \\
(0.103)\end{array}$ & $\begin{array}{l}-0.216 \\
(0.143)\end{array}$ & --- & --- & --- \\
\hline Player won arbitration & $\begin{array}{l}-0.141 \\
(0.193)\end{array}$ & $\begin{array}{l}-0.125 \\
(0.187)\end{array}$ & $\begin{array}{l}-0.121 \\
(0.172)\end{array}$ & --- & --- & --- \\
\hline Player went to arbitration & --- & --- & --- & $\begin{array}{l}-0.167 \\
(0.103)\end{array}$ & $\begin{array}{l}-0.151 \\
(0.099)\end{array}$ & $\begin{array}{l}-0.177 \\
(0.114)\end{array}$ \\
\hline
\end{tabular}


Table 4 (continued)

\begin{tabular}{|c|c|c|c|c|c|c|}
\hline \multicolumn{7}{|c|}{ Dependent variable: alternative standardized performance score $(n=1,424)$} \\
\hline Player lost arbitration & $\begin{array}{l}-0.131 \\
(0.113)\end{array}$ & $\begin{array}{l}-0.098 \\
(0.098)\end{array}$ & $\begin{array}{l}-0.070 \\
(0.118)\end{array}$ & --- & --- & --- \\
\hline Player won arbitration & $\begin{array}{l}-0.067 \\
(0.103)\end{array}$ & $\begin{array}{c}0.012 \\
(0.086)\end{array}$ & $\begin{array}{c}0.054 \\
(0.131)\end{array}$ & --- & --- & --- \\
\hline Player went to arbitration & --- & --- & --- & $\begin{array}{l}-0.105 \\
(0.082)\end{array}$ & $\begin{array}{l}-0.053 \\
(0.070)\end{array}$ & $\begin{array}{l}-0.020 \\
(0.090)\end{array}$ \\
\hline \multicolumn{7}{|c|}{ Includes players filing for arbitration who settle before exchanging offers ( $n=2,233$ ) } \\
\hline Player lost arbitration & $\begin{array}{l}-0.193 \\
(0.111)\end{array}$ & $\begin{array}{l}-0.180 \\
(0.105)\end{array}$ & $\begin{array}{l}-0.131 \\
(0.126)\end{array}$ & --- & --- & --- \\
\hline Player won arbitration & $\begin{array}{l}-0.019 \\
(0.103)\end{array}$ & $\begin{array}{l}-0.022 \\
(0.095)\end{array}$ & $\begin{array}{l}-0.022 \\
(0.127)\end{array}$ & --- & --- & --- \\
\hline Player went to arbitration & --- & --- & --- & $\begin{array}{l}-0.122 \\
(0.081)\end{array}$ & $\begin{array}{l}-0.116 \\
(0.076)\end{array}$ & $\begin{array}{l}-0.087 \\
(0.094)\end{array}$ \\
\hline $\begin{array}{l}\text { Years played, year, and } \\
\text { team effects }\end{array}$ & Yes & Yes & Yes & Yes & Yes & Yes \\
\hline Lagged performance & No & Yes & Yes & No & Yes & Yes \\
\hline Team×year effects & No & No & Yes & No & No & Yes \\
\hline
\end{tabular}

Notes: Each entry contains the estimated coefficient and robust standard error (in parentheses) from a regression model with dependent variable season-long standardized performance (weighted across multiple stints where appropriate), except the fifth model for which the dependent variable is the standardized alternative performance measure (defenseindependent ERA for pitchers and runs created for batters). Each model contains the same control variables as the corresponding column in Table 3.

Statistically significant at the $* 0.05$ or $* * 0.01$ level. 
Table 5: Does Salary Arbitration Break the Player-Club Relationship?

\begin{tabular}{|c|c|c|c|c|c|c|}
\hline & \multicolumn{3}{|c|}{$\begin{array}{c}\text { Allowing for Differential } \\
\text { Win/Lose Arb. Effects }\end{array}$} & \multicolumn{3}{|c|}{$\begin{array}{l}\text { Pooling Arbitration } \\
\text { Winners and Losers }\end{array}$} \\
\hline & (1) & (2) & (3) & (4) & (5) & (6) \\
\hline $\begin{array}{l}\text { Player lost } \\
\text { arbitration }\end{array}$ & $\begin{array}{l}0.078^{*} \\
(0.034)\end{array}$ & $\begin{array}{l}0.071^{*} \\
(0.034)\end{array}$ & $\begin{array}{c}0.078 \\
(0.040)\end{array}$ & --- & --- & --- \\
\hline $\begin{array}{l}\text { Player won } \\
\text { arbitration }\end{array}$ & $\begin{array}{c}0.149 * * \\
(0.044)\end{array}$ & $\begin{array}{c}0.147 * * \\
(0.044)\end{array}$ & $\begin{array}{c}0.152^{* *} \\
(0.055)\end{array}$ & --- & --- & --- \\
\hline $\begin{array}{l}\text { Player went to } \\
\text { arbitration }\end{array}$ & --- & --- & --- & $\begin{array}{c}0.107^{* *} \\
(0.029)\end{array}$ & $\begin{array}{l}0.102^{* *} \\
(0.029)\end{array}$ & $\begin{array}{c}0.108^{* *} \\
(0.036)\end{array}$ \\
\hline Age & $\begin{array}{c}0.067 \\
(0.043)\end{array}$ & $\begin{array}{c}0.052 \\
(0.043)\end{array}$ & $\begin{array}{c}0.045 \\
(0.047)\end{array}$ & $\begin{array}{c}0.064 \\
(0.043)\end{array}$ & $\begin{array}{c}0.049 \\
(0.043)\end{array}$ & $\begin{array}{c}0.041 \\
(0.047)\end{array}$ \\
\hline Age squared & $\begin{array}{c}-0.001 \\
(0.0007)\end{array}$ & $\begin{array}{c}-0.0009 \\
(0.0007)\end{array}$ & $\begin{array}{l}-0.0007 \\
(0.0008)\end{array}$ & $\begin{array}{c}-0.001 \\
(0.0007)\end{array}$ & $\begin{array}{l}-0.0008 \\
(0.0007)\end{array}$ & $\begin{array}{l}-0.0007 \\
(0.0008)\end{array}$ \\
\hline $\begin{array}{l}\text { Left-handed } \\
\text { batter }\end{array}$ & $\begin{array}{c}0.018 \\
(0.027)\end{array}$ & $\begin{array}{c}0.017 \\
(0.026)\end{array}$ & $\begin{array}{l}-0.012 \\
(0.030)\end{array}$ & $\begin{array}{c}0.019 \\
(0.027)\end{array}$ & $\begin{array}{c}0.018 \\
(0.026)\end{array}$ & $\begin{array}{l}-0.011 \\
(0.030)\end{array}$ \\
\hline $\begin{array}{l}\text { Right-handed } \\
\text { batter }\end{array}$ & $\begin{array}{l}-0.015 \\
(0.023)\end{array}$ & $\begin{array}{l}-0.027 \\
(0.022)\end{array}$ & $\begin{array}{l}-0.027 \\
(0.027)\end{array}$ & $\begin{array}{l}-0.013 \\
(0.023)\end{array}$ & $\begin{array}{l}-0.025 \\
(0.023)\end{array}$ & $\begin{array}{l}-0.025 \\
(0.027)\end{array}$ \\
\hline $\begin{array}{l}\text { Switch-hitting } \\
\text { batter }\end{array}$ & $\begin{array}{l}-0.019 \\
(0.035)\end{array}$ & $\begin{array}{l}-0.020 \\
(0.034)\end{array}$ & $\begin{array}{l}-0.018 \\
(0.043)\end{array}$ & $\begin{array}{l}-0.018 \\
(0.035)\end{array}$ & $\begin{array}{l}-0.018 \\
(0.034)\end{array}$ & $\begin{array}{l}-0.018 \\
(0.043)\end{array}$ \\
\hline $\begin{array}{l}\text { Left-handed } \\
\text { pitcher }\end{array}$ & $\begin{array}{l}-0.0006 \\
(0.029)\end{array}$ & $\begin{array}{l}-0.006 \\
(0.029)\end{array}$ & $\begin{array}{l}-0.016 \\
(0.034)\end{array}$ & $\begin{array}{c}0.001 \\
(0.029)\end{array}$ & $\begin{array}{l}-0.004 \\
(0.029)\end{array}$ & $\begin{array}{l}-0.013 \\
(0.034)\end{array}$ \\
\hline U.S. born & $\begin{array}{c}0.015 \\
(0.024)\end{array}$ & $\begin{array}{c}0.010 \\
(0.024)\end{array}$ & $\begin{array}{c}0.051 \\
(0.027)\end{array}$ & $\begin{array}{c}0.017 \\
(0.024)\end{array}$ & $\begin{array}{c}0.013 \\
(0.024)\end{array}$ & $\begin{array}{c}0.052 \\
(0.027)\end{array}$ \\
\hline $\begin{array}{l}\text { Prior perf., } \\
\text { previous season }\end{array}$ & --- & $\begin{array}{c}-0.057 * * \\
(0.013)\end{array}$ & $\begin{array}{c}-0.048^{* *} \\
(0.017)\end{array}$ & --- & $\begin{array}{c}-0.057 * * \\
(0.013)\end{array}$ & $\begin{array}{c}-0.048^{* *} \\
(0.017)\end{array}$ \\
\hline $\begin{array}{l}\text { Prior perf., two } \\
\text { seasons previous }\end{array}$ & --- & $\begin{array}{l}-0.005 \\
(0.009)\end{array}$ & $\begin{array}{c}0.003 \\
(0.010)\end{array}$ & --- & $\begin{array}{l}-0.005 \\
(0.009)\end{array}$ & $\begin{array}{c}0.003 \\
(0.010)\end{array}$ \\
\hline $\begin{array}{l}\text { Years played, } \\
\text { year, and team } \\
\text { effects }\end{array}$ & Yes & Yes & Yes & Yes & Yes & Yes \\
\hline $\begin{array}{l}\text { Team×year } \\
\text { effects }\end{array}$ & No & No & Yes & No & No & Yes \\
\hline
\end{tabular}


Table 5 (continued)

\begin{tabular}{lcccccc}
\hline $\begin{array}{l}\text { p-value for } \\
\text { equality of player } \\
\begin{array}{l}\text { lost and player } \\
\text { won }\end{array}\end{array}$ & 0.175 & 0.140 & 0.240 & --- & --- & --- \\
Adjusted $\mathrm{R}^{2}$ & 0.044 & 0.059 & 0.190 & 0.043 & 0.058 & 0.189 \\
\hline
\end{tabular}

Notes: Each entry contains the estimated coefficient and robust standard error (in parentheses) from a regression model with (except where specified) dependent variable equal to 1 if the player is not with the arbitration team at the end of the season. Sample size is 1,424 .

Statistically significant at the * 0.05 or ** 0.01 level. 
Table 6: Salary Arbitration and Relationship Breakup: Robustness Checks

\begin{tabular}{|c|c|c|c|c|c|c|}
\hline & \multicolumn{3}{|c|}{$\begin{array}{l}\text { Allowing for Differential } \\
\text { Win/Lose Arb. Effects }\end{array}$} & \multicolumn{3}{|c|}{$\begin{array}{l}\text { Pooling Arbitration } \\
\text { Winners and Losers }\end{array}$} \\
\hline & (1) & (2) & (3) & (4) & (5) & (6) \\
\hline \multicolumn{7}{|c|}{ Baseline Results $(n=1,424)$} \\
\hline Player lost arbitration & $\begin{array}{l}0.078^{*} \\
(0.034)\end{array}$ & $\begin{array}{l}0.071^{*} \\
(0.034)\end{array}$ & $\begin{array}{c}0.078 \\
(0.040)\end{array}$ & --- & --- & --- \\
\hline Player won arbitration & $\begin{array}{l}0.149 * * \\
(0.044)\end{array}$ & $\begin{array}{l}0.147 * * \\
(0.044)\end{array}$ & $\begin{array}{l}0.152 * * \\
(0.055)\end{array}$ & --- & --- & --- \\
\hline $\begin{array}{l}\text { Player went to } \\
\text { arbitration }\end{array}$ & --- & --- & --- & $\begin{array}{l}0.107 * * \\
(0.029)\end{array}$ & $\begin{array}{l}0.102^{* *} \\
(0.029)\end{array}$ & $\begin{array}{l}0.108^{* *} \\
(0.036)\end{array}$ \\
\hline \multicolumn{7}{|c|}{ Probit marginal effects ( $\mathrm{n}=1,424 ; \mathrm{n}=530$ in columns 3 and 6 ) } \\
\hline Player lost arbitration & $\begin{array}{l}0.079 * * \\
(0.035)\end{array}$ & $\begin{array}{c}0.065^{*} \\
(0.033)\end{array}$ & $\begin{array}{l}0.118^{* *} \\
(0.119)\end{array}$ & --- & --- & --- \\
\hline Player won arbitration & $\begin{array}{l}0.159 * * \\
(0.048)\end{array}$ & $\begin{array}{l}0.152 * * \\
(0.047)\end{array}$ & $\begin{array}{c}0.222^{* *} \\
(0.184)\end{array}$ & --- & --- & --- \\
\hline $\begin{array}{l}\text { Player went to } \\
\text { arbitration }\end{array}$ & --- & --- & --- & $\begin{array}{l}0.106^{* *} \\
(0.029)\end{array}$ & $\begin{array}{l}0.095^{* *} \\
(0.028)\end{array}$ & $\begin{array}{c}0.150^{* *} \\
(0.123)\end{array}$ \\
\hline \multicolumn{7}{|c|}{ 3-7 Years of Service $(n=1,325)$} \\
\hline Player lost arbitration & $\begin{array}{c}0.064 \\
(0.035)\end{array}$ & $\begin{array}{c}0.056 \\
(0.034)\end{array}$ & $\begin{array}{c}0.045 \\
(0.040)\end{array}$ & --- & --- & --- \\
\hline Player won arbitration & $\begin{array}{c}0.133^{* *} \\
(0.046)\end{array}$ & $\begin{array}{l}0.132^{* *} \\
(0.045)\end{array}$ & $\begin{array}{l}0.152^{*} \\
(0.060)\end{array}$ & --- & --- & --- \\
\hline $\begin{array}{l}\text { Player went to } \\
\text { arbitration }\end{array}$ & --- & --- & --- & $\begin{array}{l}0.093 * * \\
(0.030)\end{array}$ & $\begin{array}{l}0.087 * * \\
(0.029)\end{array}$ & $\begin{array}{l}0.088^{*} \\
(0.037)\end{array}$ \\
\hline
\end{tabular}


Dependent variable: 1 if player moves to a new team before start of post-arbitration season $\underline{(n=1,424)}$

$\begin{array}{lccc}\text { Player lost arbitration } & 0.059 * * & 0.056 * * & 0.069 * * \\ & (0.022) & (0.021) & (0.024) \\ \text { Player won arbitration } & 0.082 * * & 0.081^{* *} & 0.108 * * \\ & (0.031) & (0.030) & (0.037)\end{array}$

Player went to

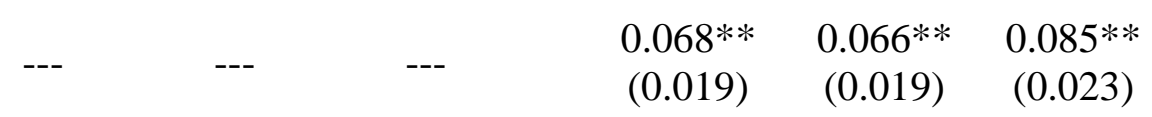
arbitration

Includes players filing for arbitration who settle before exchanging offers $(n=2,233)$

\begin{tabular}{|c|c|c|c|c|c|c|}
\hline Player lost arbitration & $\begin{array}{l}0.074 * \\
(0.033)\end{array}$ & $\begin{array}{l}0.070 * \\
(0.033)\end{array}$ & $\begin{array}{l}0.075^{*} \\
(0.036)\end{array}$ & --- & --- & --- \\
\hline Player won arbitration & $\begin{array}{c}0.140 * * \\
(0.044)\end{array}$ & $\begin{array}{c}0.143 * * \\
(0.043)\end{array}$ & $\begin{array}{c}0.160 * * \\
(0.046)\end{array}$ & --- & --- & --- \\
\hline $\begin{array}{l}\text { Player went to } \\
\text { arbitration }\end{array}$ & --- & --- & --- & $\begin{array}{l}0.101^{* *} \\
(0.028)\end{array}$ & $\begin{array}{l}0.100 * * \\
(0.028)\end{array}$ & $\begin{array}{l}0.110 * * \\
(0.030)\end{array}$ \\
\hline $\begin{array}{l}\text { Years played, year, and } \\
\text { team effects }\end{array}$ & Yes & Yes & Yes & Yes & Yes & Yes \\
\hline Lagged performance & No & Yes & Yes & No & Yes & Yes \\
\hline Team×year effects & No & No & Yes & No & No & Yes \\
\hline
\end{tabular}

Notes: Each entry contains the estimated coefficient and robust standard error (in parentheses) from a regression model with (except where specified) dependent variable equal to 1 if the player is not with the arbitration team at the end of the season. Each model contains the same control variables as the corresponding column in Table 7.

Statistically significant at the $* 0.05$ or $* * 0.01$ level. 
Table 7: Dispute Intensity Results: Performance

\begin{tabular}{|c|c|c|c|c|c|c|}
\hline & \multicolumn{3}{|c|}{$\begin{array}{l}\text { Allowing for Differential } \\
\text { Win/Lose Arb. Effects }\end{array}$} & \multicolumn{3}{|c|}{$\begin{array}{l}\text { Pooling Arbitration } \\
\text { Winners and Losers }\end{array}$} \\
\hline & $(1)$ & (2) & (3) & (4) & (5) & (6) \\
\hline Player lost arbitration & $\begin{array}{l}-0.195 \\
(0.104)\end{array}$ & $\begin{array}{l}-0.160 \\
(0.103)\end{array}$ & $\begin{array}{l}-0.127 \\
(0.228)\end{array}$ & --- & --- & --- \\
\hline Player won arbitration & $\begin{array}{l}-0.002 \\
(0.096)\end{array}$ & $\begin{array}{c}0.009 \\
(0.095)\end{array}$ & $\begin{array}{c}0.145 \\
(0.215)\end{array}$ & --- & --- & --- \\
\hline Player went to arbitration & --- & --- & --- & $\begin{array}{l}-0.116 \\
(0.074)\end{array}$ & $\begin{array}{l}-0.090 \\
(0.074)\end{array}$ & $\begin{array}{l}-0.013 \\
(0.167)\end{array}$ \\
\hline $\begin{array}{l}\text { Salary disagreement } \\
\text { (difference in exchanged } \\
\text { offers as fraction of } \\
\text { average offer) }\end{array}$ & --- & $\begin{array}{c}-0.812 * * \\
(0.228)\end{array}$ & $\begin{array}{c}-0.769 * * \\
(0.278)\end{array}$ & --- & $\begin{array}{c}-0.827 * * \\
(0.228)\end{array}$ & $\begin{array}{c}-0.773 * * \\
(0.278)\end{array}$ \\
\hline $\begin{array}{l}\text { Salary disagreement } \times \\
\text { Player lost arbitration }\end{array}$ & --- & --- & $\begin{array}{l}-0.095 \\
(0.537)\end{array}$ & --- & --- & --- \\
\hline $\begin{array}{l}\text { Salary disagreement } \times \\
\text { Player won arbitration }\end{array}$ & --- & --- & $\begin{array}{l}-0.406 \\
(0.601)\end{array}$ & --- & --- & --- \\
\hline $\begin{array}{l}\text { Salary disagreement } \times \\
\text { Player went to arbitration }\end{array}$ & --- & --- & --- & --- & --- & $\begin{array}{l}-0.222 \\
(0.439)\end{array}$ \\
\hline $\begin{array}{l}\text { Baseline control variables } \\
\text { including lagged } \\
\text { performance }\end{array}$ & Yes & Yes & Yes & Yes & Yes & Yes \\
\hline $\begin{array}{l}\text { Years played, year, and } \\
\text { team effects }\end{array}$ & Yes & Yes & Yes & Yes & Yes & Yes \\
\hline Adjusted $\mathrm{R}^{2}$ & 0.144 & 0.151 & 0.150 & 0.144 & 0.151 & 0.150 \\
\hline
\end{tabular}

Notes: Each entry contains the estimated coefficient and robust standard error (in parentheses) from a regression model with dependent variable season-long earned run average (weighted across multiple stints where appropriate). Sample size is 1,423.

Statistically significant at the $* 0.05$ or $* * 0.01$ level. 
Table 8: Dispute Intensity Results: Relationship Breakup

\begin{tabular}{|c|c|c|c|c|c|c|}
\hline & \multicolumn{3}{|c|}{$\begin{array}{l}\text { Allowing for Differential } \\
\text { Win/Lose Arb. Effects }\end{array}$} & \multicolumn{3}{|c|}{$\begin{array}{l}\text { Pooling Arbitration } \\
\text { Winners and Losers }\end{array}$} \\
\hline & (1) & (2) & (3) & (4) & (5) & (6) \\
\hline Player lost arbitration & $\begin{array}{l}0.071^{*} \\
(0.034)\end{array}$ & $\begin{array}{l}0.069 * \\
(0.033)\end{array}$ & $\begin{array}{c}0.010 \\
(0.083)\end{array}$ & --- & --- & --- \\
\hline Player won arbitration & $\begin{array}{l}0.147 * * \\
(0.044)\end{array}$ & $\begin{array}{c}0.147 * * \\
(0.044)\end{array}$ & $\begin{array}{c}0.195 \\
(0.113)\end{array}$ & --- & --- & --- \\
\hline Player went to arbitration & --- & --- & --- & $\begin{array}{c}0.102 * * \\
(0.029)\end{array}$ & $\begin{array}{l}0.101^{* *} \\
(0.029)\end{array}$ & $\begin{array}{c}0.080 \\
(0.070)\end{array}$ \\
\hline $\begin{array}{l}\text { Salary disagreement } \\
\text { (difference in exchanged } \\
\text { offers as fraction of } \\
\text { average offer) }\end{array}$ & --- & $\begin{array}{c}0.044 \\
(0.072)\end{array}$ & $\begin{array}{c}0.024 \\
(0.077)\end{array}$ & --- & $\begin{array}{c}0.038 \\
(0.072)\end{array}$ & $\begin{array}{c}0.023 \\
(0.077)\end{array}$ \\
\hline $\begin{array}{l}\text { Salary disagreement } \times \\
\text { Player lost arbitration }\end{array}$ & --- & --- & $\begin{array}{c}0.164 \\
(0.221)\end{array}$ & --- & --- & --- \\
\hline $\begin{array}{l}\text { Salary disagreement } \times \\
\text { Player won arbitration }\end{array}$ & --- & --- & $\begin{array}{l}-0.145 \\
(0.301)\end{array}$ & --- & --- & --- \\
\hline $\begin{array}{l}\text { Salary disagreement } \times \\
\text { Player went to arbitration }\end{array}$ & --- & --- & --- & --- & --- & $\begin{array}{c}0.061 \\
(0.187)\end{array}$ \\
\hline $\begin{array}{l}\text { Baseline control variables } \\
\text { including lagged } \\
\text { performance }\end{array}$ & Yes & Yes & Yes & Yes & Yes & Yes \\
\hline $\begin{array}{l}\text { Years played, year, and } \\
\text { team effects }\end{array}$ & Yes & Yes & Yes & Yes & Yes & Yes \\
\hline Adjusted $\mathrm{R}^{2}$ & 0.059 & 0.058 & 0.058 & 0.057 & 0.057 & 0.056 \\
\hline
\end{tabular}

Notes: Each entry contains the estimated coefficient and robust standard error (in parentheses) from a regression model with dependent variable equal to 1 if the player is not with the arbitration team at the end of the season. Sample size is 1,423.

Statistically significant at the $* 0.05$ or $* * 0.01$ level. 
Table 9: Margin of Victory Results

\begin{tabular}{|c|c|c|c|c|}
\hline & \multicolumn{2}{|c|}{ Player Performance } & \multicolumn{2}{|c|}{ Relationship Break-Up } \\
\hline & (1) & (2) & (3) & (4) \\
\hline Player lost arbitration & $\begin{array}{l}-0.029 \\
(0.111)\end{array}$ & $\begin{array}{l}-0.028 \\
(0.564)\end{array}$ & $\begin{array}{c}0.065 \\
(0.035)\end{array}$ & $\begin{array}{c}0.243 \\
(0.233)\end{array}$ \\
\hline Player won arbitration & $\begin{array}{l}-0.181 \\
(0.104)\end{array}$ & $\begin{array}{l}-0.181 \\
(0.106)\end{array}$ & $\begin{array}{l}0.154^{* *} \\
(0.046)\end{array}$ & $\begin{array}{c}0.290 \\
(0.283)\end{array}$ \\
\hline $\begin{array}{l}\text { Salary settlement as a } \\
\text { fraction of player's final } \\
\text { offer }\end{array}$ & $\begin{array}{c}1.169 * * \\
(0.295)\end{array}$ & $\begin{array}{c}1.169 * * \\
(0.330)\end{array}$ & $\begin{array}{c}-0.044 \\
(0.098)\end{array}$ & $\begin{array}{c}-0.010 \\
(0.104)\end{array}$ \\
\hline $\begin{array}{l}\text { Salary settlement as a } \\
\text { fraction of player's final } \\
\text { offer } \times \text { Player lost } \\
\text { arbitration }\end{array}$ & --- & $\begin{array}{c}-0.001 \\
(0.775)\end{array}$ & --- & $\begin{array}{c}-0.247 \\
(0.319)\end{array}$ \\
\hline $\begin{array}{l}\text { Salary settlement as a } \\
\text { fraction of club’s final } \\
\text { offer }\end{array}$ & --- & --- & $\begin{array}{l}-0.0005 \\
(0.056)\end{array}$ & $\begin{array}{c}0.004 \\
(0.058)\end{array}$ \\
\hline $\begin{array}{l}\text { Salary settlement as a } \\
\text { fraction of club’s final } \\
\text { offer } \times \text { Player won } \\
\text { arbitration }\end{array}$ & --- & --- & --- & $\begin{array}{c}-0.101 \\
(0.195)\end{array}$ \\
\hline $\begin{array}{l}\text { Baseline control variables } \\
\text { including lagged } \\
\text { performance }\end{array}$ & Yes & Yes & Yes & Yes \\
\hline $\begin{array}{l}\text { Years played, year, and } \\
\text { team effects }\end{array}$ & Yes & Yes & Yes & Yes \\
\hline Adjusted $\mathrm{R}^{2}$ & 0.153 & 0.153 & 0.058 & 0.057 \\
\hline
\end{tabular}

Notes: Each entry contains the estimated coefficient and robust standard error (in parentheses) from a regression model with dependent variable season-long standardized performance (columns 1 and 2) or dependent variable equal to 1 if the player is not with the arbitration team at the end of the season (columns 3 and 4). Sample size is 1,423 .

Statistically significant at the $* 0.05$ or $* * 0.01$ level. 